\title{
Busana Dengan Jahitan Tangan (Hand Sewing) Di Kampung Malaus Kabupaten Sorong
}

\author{
Mitta Muthia Wangsi ${ }^{1}$, Wisang Candra Bintari², Suntinah ${ }^{1}$ \\ 1,2,3 Fakultas Ekonomi, Universitas Muhammadiyah Sorong, Indonesia \\ Email. mithamuthia@gmail.com
}

\begin{abstract}
ABSTRAK
Pelatihan ini bertujuan untuk membentuk sikap wirausaha mengembangkan bakat serta memberikan peluang bisnis bagi peserta melalui pelatihan menjahit yang dilaksanakan dikampung malaus. Penelitian ini menggunakan pendekatan kualitatif. Hasil penelitian menunjukan adanya keberhasilan pelatihan menjahit kepada peserta dengan diperolehnya sikap wirausaha diantaranya: kemauan dan rasa percaya diri, disiplin, motifasi tinggi berani mengambil resiko, kreatif dan inovasi tinggi. Beberapa faktor pendukungnya yaitu minat dan semangat yang tinggi yang ada pada peserta dalam menjalani pelatihan menjahit sehingga pelatihan tersebut dapat berjalan dengan baik. Dalam pelaksanaan menjahit diperlukan cukup banyak persiapan seperti bahan dan peralatan menjahit, berbagai metode jahit yang telah diajarkan tentunya akan sangat bermanfaat baik bagi diri sendiri maupun dalam pengembangan ekonomi kreatif.
\end{abstract}

Kata Kunci: Busana; Jahitan tangan;Kampung Malaus

\section{Hand Sewing Clothes (Hand Sewing) in Malaus Village, Sorong Regency}

\begin{abstract}
This training aims to form entrepreneurial attitudes to develop talents and provide business opportunities for participants through sewing training held in the village of Malaus. This research uses a qualitative approach. The results showed the success of sewing training for participants by obtaining entrepreneurial attitudes including: willingness and self-confidence, discipline, high motivation to take risks, creative and high innovation. Some of the supporting factors are the high interest and enthusiasm of the participants in undergoing sewing training so that the training can run well. In the implementation of sewing, it requires quite a lot of preparation such as sewing materials and equipment, the various sewing methods that have been taught will certainly be very beneficial both for oneself and in developing the creative economy.
\end{abstract}

Keywords: Clothing; Hand stitching; Malaus Village

\section{PENDAHULUAN}

Di Indonesia saat ini masih menghadapi permasalahan ketenagakerjaan yang masih sangat kompleks. Jumlah pengangguran secara kumulatif terus meningkat sejalan dengan meningkatnya jumlah lulusan pendidikan sekolah. (Nurpitriani, 2017). Dalam usia produktif lapangan pekerjaan yang tersedia cukup tinggi, akan tetapi dihadapkan pada kurangnya skil atau keterampilan yang kurang memadai. (Citra Kunia putri dan trisna insan Noor, 2013). Seperti yang terjadi dikampung malaus, rata-rata penduduknya tidak bekerja, karena kurangnya skil pada tiap individu.

Hal tersbut mengakibatkan jumlah pengangguran dikabupaten sorong terus meningkat setiap tahun. Busana merupakan salah satu hal pokok dalam kehidupan yang selalu mengikuti perkembangan zaman yang ada. Semakin berkembangnya suatu ilmu pengetahuan dan teknologi maka manusia semakin terampil dalam menciptakan suatu busana atau pakaian, busana tidak hanya berfungsi sebagai penutup atau pelindung tubuh tapi busana kini dibuat untuk memberi nilai keindahan bagi pemakainya dengan bermacam-macam model dan selalu berubah. Serta dapat berfungsi untuk menutupi kekurangan seseorang. (Pitaloka, 2007). Kurangnya kesadaran masyarakat kampung malaus tentang peluang pengembangan bisnis inilah yang memotifasi diadakannya pelatihan menjahit.

Pelatihan merupakan bagian pendidikan yang menyangkut proses belajar yang dilaksanakan diluar system pendidikan sekolah, memerlukan waktu yang singkat, dan lebih menekankan pada praktek serta berkaitan dengan kebutuhan dunia kerja maupun dalam lingkungan masyarakat yang lebih luas. (Pelatihan \& Aisyah, 2020). Masyarakat yang tidak mampu melanjutkan Pendidikan kejenjang yang lebih tinggi maupun bekerja diharapkan mereka menyiapkan masa depannya dengan keterampilan. (Septyana, 2013). 
Melalui pelatihan ini diharapkan peserta pelatihan dapat memanfaatkan waktu luangnya dengan kegiatan yang positif dan produktif, serta dapat menjadi salah satu peluang ekonomi kreatif yang dapat membantu perekonomian dimasa mendatang.Peserta pelatihan akan mempelajari pengetahuan dan keterampilan yang sifatnya praktis untuk tujuan tertentu. Para peserta akan menjadi lebih terampil dan karenanya akan lebih produktif sekalipun manfaat-manfaat tersebut harus diperhitungkan dengan waktu. (MK Bajuri, 2015)

Dalam pembuatan produk busana ada berbagai cara yang dapat digunakan untuk dapat menyelesaikan busana yang ingin diciptakan salah satunya dengan jahitan tangan. Menjahit dengan tangan merupakan segala kegiatan yang pengerjaannya semata mata dengan tangan, seperti memasang kancing berlobang, kancing jepret, kancing kait dan lain-lain. Jahitan tangan sangat diperlukan untuk berbagai kebutuhan finishing busana, salah satunya menjahit aksesoris. Dengan pengembangan kreatifitas dan keterampilan, seseorang dapat dengan mudah membuat sebuah busana. Pengembangan kreatifitas dapat dilakukan dengan berbagai cara salah satunya dengan mengikuti pelatihan jahitan tangan

Menghadapi persoalan pengangguran yang bertumpu pada semakin sempitnya pasar kerja disertai kurangnya life skil perlu dilakukan langkah-langkah yang mengarah pada peningkatan kualitas SDM melalui program pelatihan. Menurut hasil penelitian yang dilakukan Rindi (2015) yang dikutip oleh Asfinda (2017:102) menunjukan bahwa program pelatihan life skil menjahit selain berpengaruh terhadap pengetahuan peserta juga dapat berpengaruh pada sikap kemandirian peserta didik. Sikap kemandirian yang tumbuh setelah pelatihan antara lain peserta didik memiliki motovasi untuk bekerja lebih giat, yang dibuktikan dengan diterimanya peserta dipabrik garment di daerah, sikap memiliki tanggung jawab dan tidak bergantung pada orang lain dibuktikan peserta didik melalui usaha jahit yang dibukanya sendiri. Dari penelitian tersebut, menggambarkan bahwa pelatihan memiliki pengaruh dalam perubahan perilaku berupa bertambahnya pengetahuan, keahlian, keterampilan, dan juga tumbuhnya sikap kemandirian. (YENIS FIRISKA, 2017)

Dilihat dari letak wilayahnya yang cukup terpencil dan tertinggal tentunya mempengaruhi SDM yang ada dikampung malaus, belum lagi permasalahan pendidikan. Banyak sekali remaja yang putus sekolah dikarenakan masalah ekonomi, warganya yang tidak memiliki keterampilan, serta kurangnya peluang bisnis yang ada disana. Tujuan dari pelaksanaan pelatihan menjahit kepada warga kampung malaus kabupaten sorong diharapkan dapat meningkatkan kualitas dan produktifitas para warga sehingga dapat meningkatkan perekonomian dan mendapat bekal keterampilan menjahit yang dapat diterapkan sebagai peluang bisnis yang menghasilkan tambahan pemasukan bagi warga dikemudian hari. Serta dapat memberi peluang pengembangan bakat warga yang memiliki keterbatasan ekonomi.

\section{METODE PENELITIAN}

\section{Tempat dan Peserta}

Penelitian ini dilakukan digedung serbaguna jalan dahlia kampung malaus kabupaten Sorong. Adapun peserta pelatihan terdiri dari ibu-ibu yang tergabung dalam anggota PKK dan remaja-remaja yang tidak lulus SMA kampung malaus kabupaten sorong. Total peserta yang mengikuti pelatihan yaitu 70 orang. 


\section{Bahan dan Alat Pelatihan}

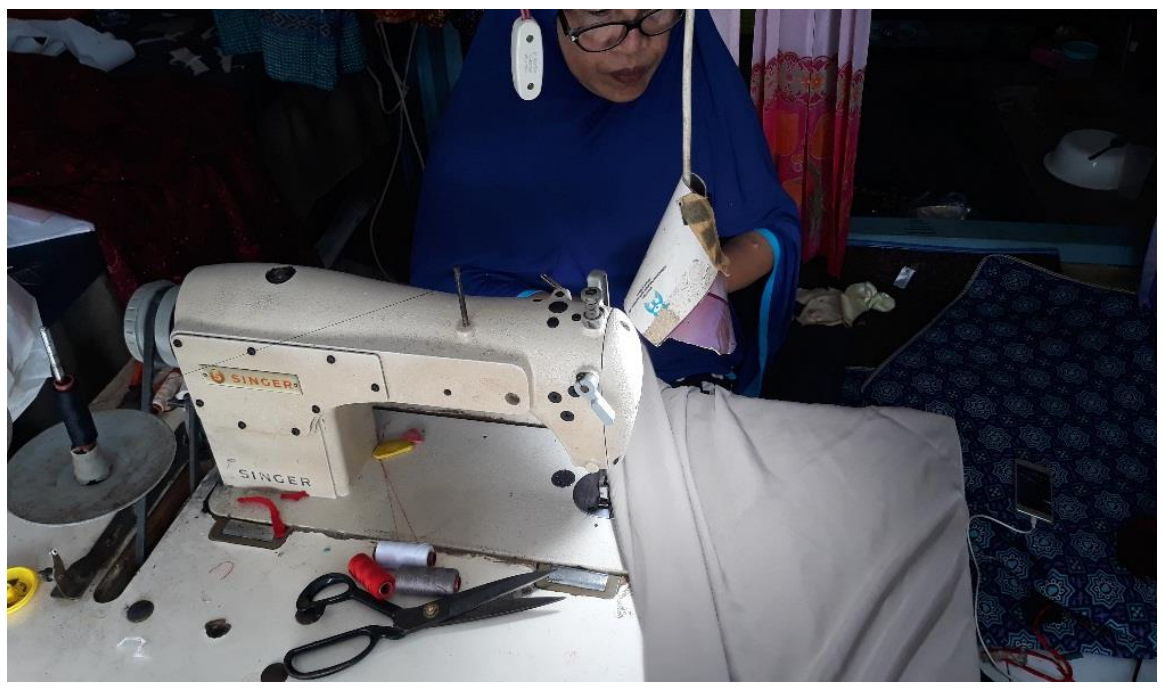

Gambar 1. Alat dan Bahan Menjahit

Alat dan bahan yang digunakan untuk menjahit dengan tangan adalah sebagai berikut, jarum tangan, jarum pentul, pengait benang, bidal/topi jari, pendedel/pembuka jahitan, gunting benang, gunting kain, kapur jahit/pensil jahit, pita ukur/meteran ,setrika listrik, perca bahan/kain, macam-macam kancing, busana yang akan diselesaikan, benang.

\section{Tahap Pelatihan}

a) Menyiapkan tempat kerja

b) Sikap kerja yang positif

c) Penyelesaian busana dengan jahitan tangan

\section{HASIL DAN PEMBAHASAN}

\section{Menyiapkan Tempat Kerja}

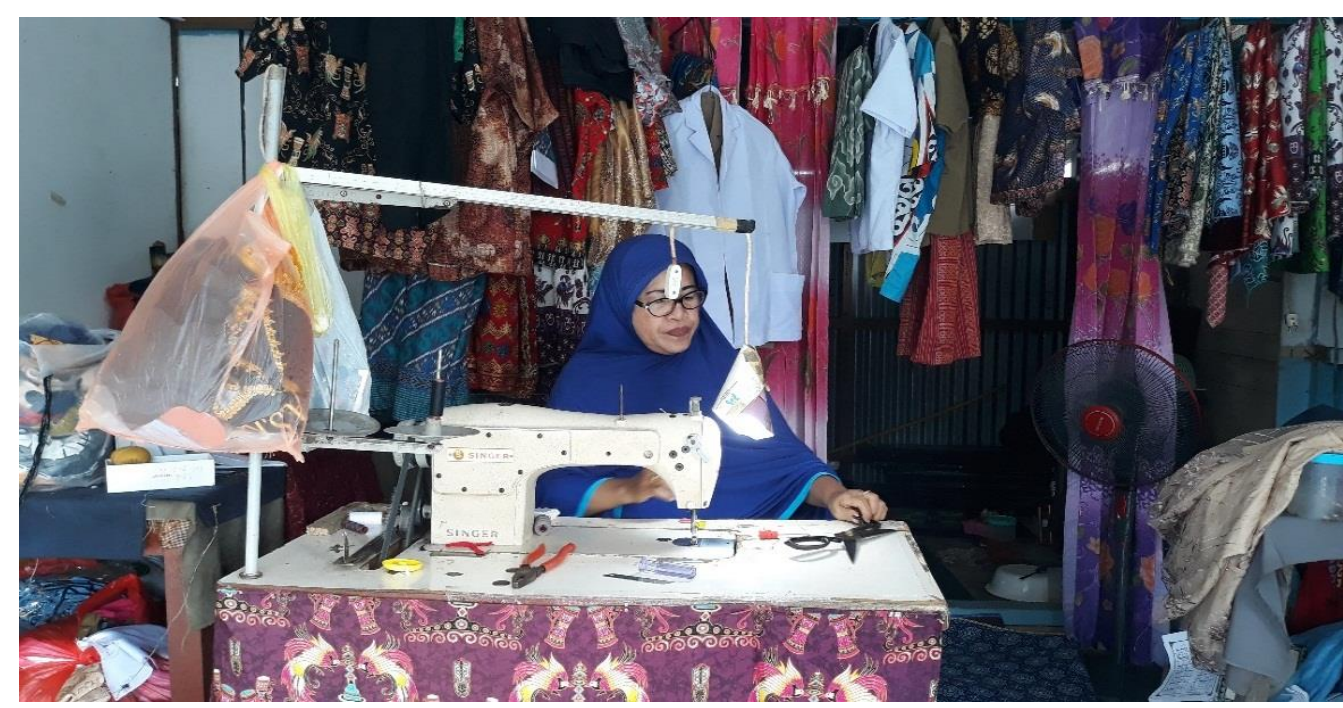

Gambar 2. Menyiapkan Tempat Kerja

Suatu tempat kerja yang diatur teliti dengan mengingat tertib kerja dan rasa keindahan, akan menyebabkan peserta pelatihan atau karyawan sebuah usaha busana dan seorang ibu rumah tangga yang sedang menjahit, tentu akan bisa bekerja dengan senang. Untuk itu ruang menjahit tangan, sebaiknya disiapkan tempat kerja seasri mungkin, serta alat yang dibutuhkan disusun sesuai dengan tertib kerja sehingga dapat menambah keindahan dan dayaguna praktek menjahit. 


\section{Sikap Kerja yang Positif}

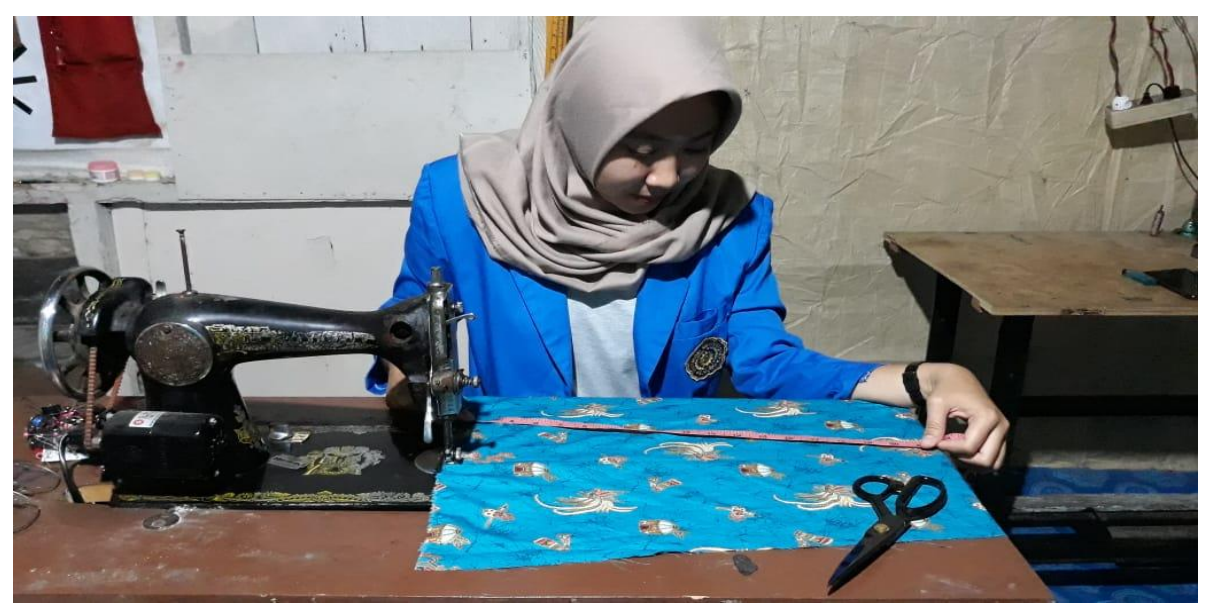

Gambar 3. Posisi Kerja Yang Positif

Dalam mengerjakan penyelesaian busana dengan alat jahit tangan, waktu bekerja harus memperhatikan sikap kerja yang positif. Duduk dengan benar, tidak hanya membantu untuk melakukan pekerjaan yang lebih baik, tetapi juga membuat pekerjaan lebih mudah dan mencegah dari rasa lelah yang muncul secara cepat. Sikap duduk yang baik adalah posisi duduk yang nyaman, tidak kaku, posisi tegak dan punggung tetap lurus. Tempatkan kedua kaki diatas lantai, siku disamping badan dan peganglah jahitan diatas meja, sehingga membawa pekerjaan pada jarak yang tepat dari mata. Posisikan tangan untuk dapat bekerja dengan nyaman diatas meja.

Pencahayaan harus cukup terang saat menyelesaika jahitan.Tangan harus dalam keadaan bersih saat memegang pekerjaan. Oleh karena itu, cuci tangan sebelum menjahit. Jika tangan menjadi basah pada waktu bekerja, cuci tangan atau taburi dengan sedikit bedak tabur.

\section{Penyelesaian Busana dengan Alat Jahit Tangan}

\section{Tusuk Dasar Menjahit}

Tusuk dasar yaitu tusuk dengan menggunakan alat jarum tangan. Ada beberapa tusuk dasar yang biasa digunakan dalam menjahit busana, antara lain sebagai berikut:

a. Tusuk Jelujur; Tusuk jelujur dapat dibedakan menjadi tiga bentuk, tusuk jelujur biasa, tusuk jelujur dengan jarak tertentu, tusuk jelujur renggang

b. Tusuk Tikam Jejak; Teknik menjahitnya adalah dengan langkah maju sebelum melangkah mundur kebelakang dengan jarak yang sama, tusuk tikam jejak berguna untuk pengganti jahit mesin.

c. Tusuk flanel ; Tusuk flanel biasa digunakan untuk mengelim pinggiran busana yang diobras.

d. Tusuk Feston ; Tusuk Feston berfungsi untuk penyelesaian tiras seperti tiras lingkar kerung lengan atau pada pinggiran pakaian bayi.

e. Tusuk Balut; Tusuk balut berfungsi untuk menyelesaikan tiras pad kampuh untuk klim rol.

f. Tusuk Batang/tangkai ; Tusuk batang dibuat untuk hiasan.

g. Tusuk Rantai; Tusuk rantai fungsinya untuk membuat hiasan .

h. Tusuk Silang ; Tusuk ini berfungsi untuk membuat hiasan.

i. Tusuk Piquar; Tusuk piquar biasanya berfungsi untuk memasang bulu kuda pada jas atau mantel. 


\section{Menjahit Tepi Pakaian}

Menjahit tepi pakaian yang terdapat pada tepi leher, kerung lengan, tepi kelim (bawah rok, blus, ujung lengan) dan sebagainya. Untuk lebih jelasnya dapat dilihat satu per satu.

Teknik Mengelim

a) Kelim sumsang

b) Kelim Tusuk Flanel

c) Kelim yang dirompok

d) Kelim Palsu

e) Kelim Rol

\section{Membuat Garis Leher/Rompok yang Tapak}

Jika bahan pelapis kelihatan karena bahannya tipis, maka garis leher ini memberikan penyelesaian yang rapi. Sesuai tepi bahan pelapis dengan tepi bahan.

\section{Membalik Kerah Kemeja}

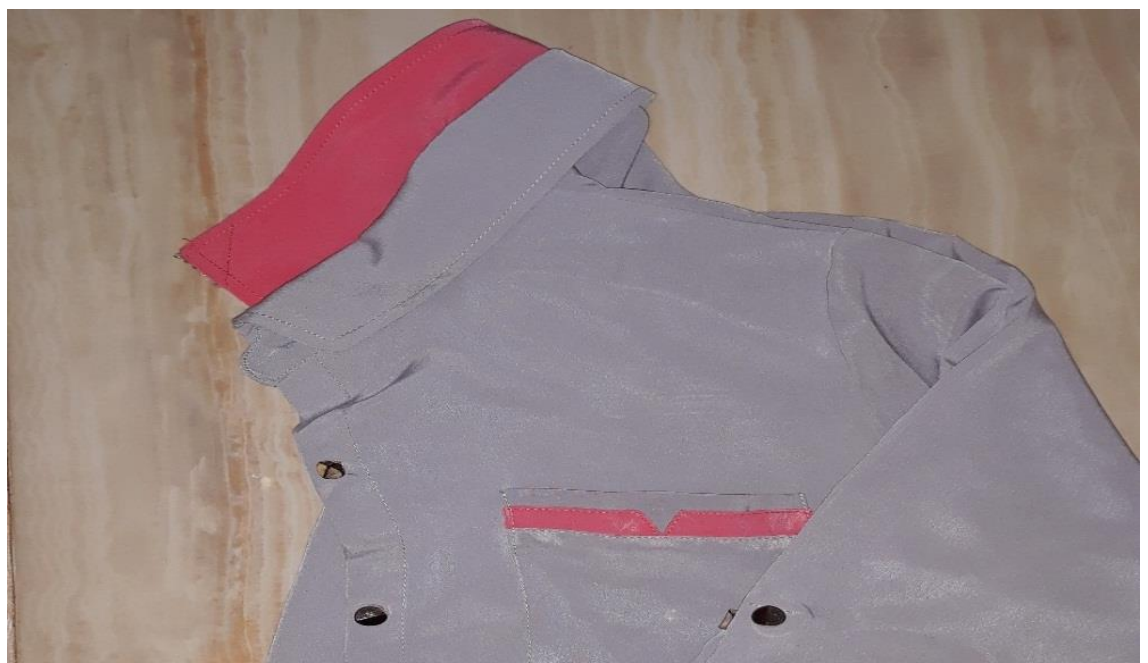

Gambar 4. Kerah Baju

Untuk membalik sudut kearah kemeja, buatlah tusuk simpul pada sudut lancipnya, lalu tusuk jarum keluar. Balik kearah dan Tarik jarum hingga mendapat sudut yang runcing. Potong habis benang.

\section{Membentuk Lingkaran Lengan, Supaya Lebih Mudah Bila dipasangkan pada badan Menutup sambungan sudut}

\section{Membuat Rumah Kancing Kait Dengan Tusuk Feston}

Membuat rumah kancing kait terbilang mudah. Rumah kancing kait biasanya digunakan untuk pakaian berupa kebaya dan gaun, agar terkesan lebih elegan karena menggunakan benang yang memiliki warna yang sama dengan busana..

\section{Memasang Kancing}

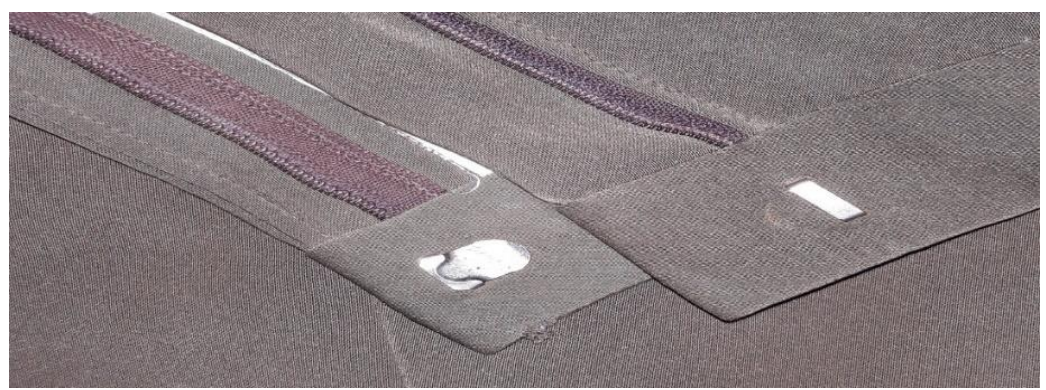

Gambar 5. Memasang Kancing 
Kancing berfungsi untuk mengancingkan belahan (penutup belahan) atau juga untuk hiasan atau variasi busana. Bermacam-macam bentuk dan model kancing, yaitu:

\section{Posisi kancing dan Lubang kancing}

Lubang kancing dapat dibuat membujur atau melintang. Untuk lubang kancing membujur, jahit kancing ditengah atau diatas lubang kancing.

$>\quad$ Lubang kancing Melintang

$>\quad$ Lubang Kancing Membujur

\section{Memasang Kancing}

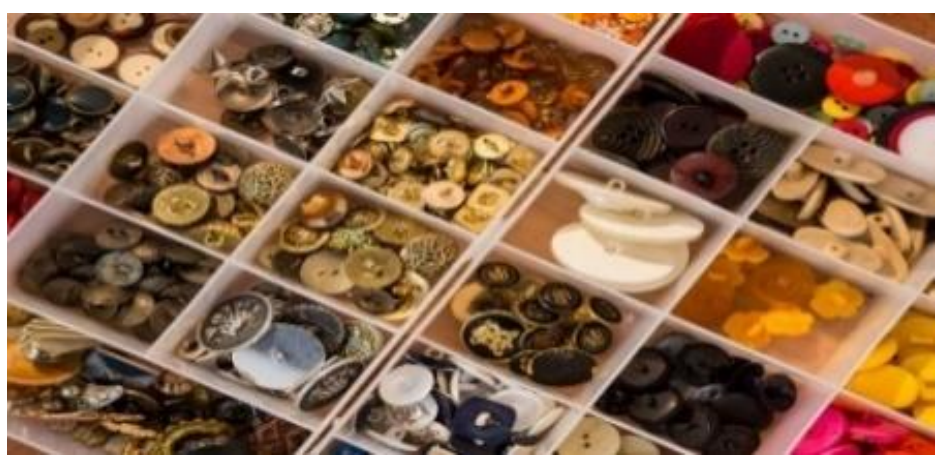

Gambar 6. Macam-macam Kancing

$>\quad$ Kancing Dua Lubang

$>$ Kancing Empat Lubang.

$>\quad$ Kancing Berkaki

$>\quad$ Kancing kait dan Mata Kait

$>\quad$ Kancing Jepret

$>\quad$ Kancing Cina

$>\quad$ Membuat Kaki Benang

\section{Membuat Lubang Kancing/ Rumah Kancing Blazer/Jas}

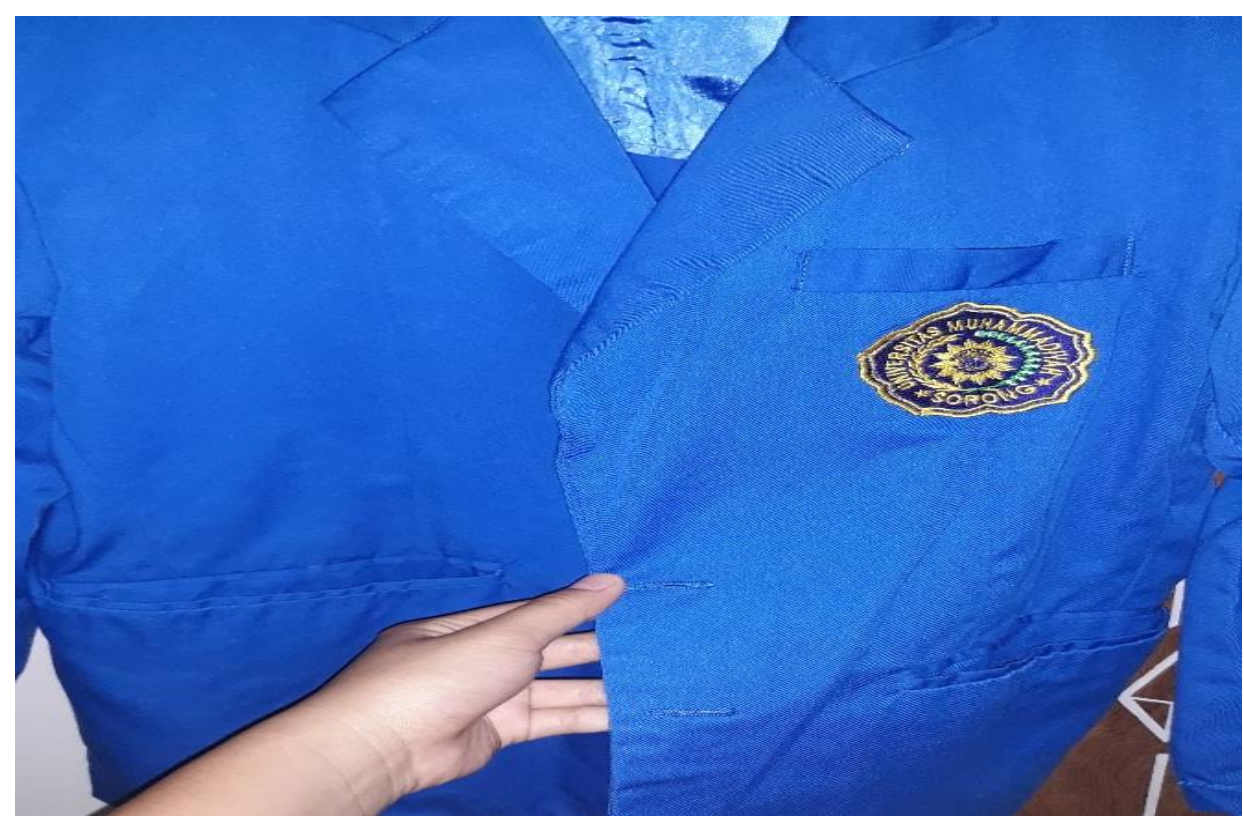

Gambar 7. Lubang kancing pada jas 


\section{Membuat Furing pada Gaun/Rok}

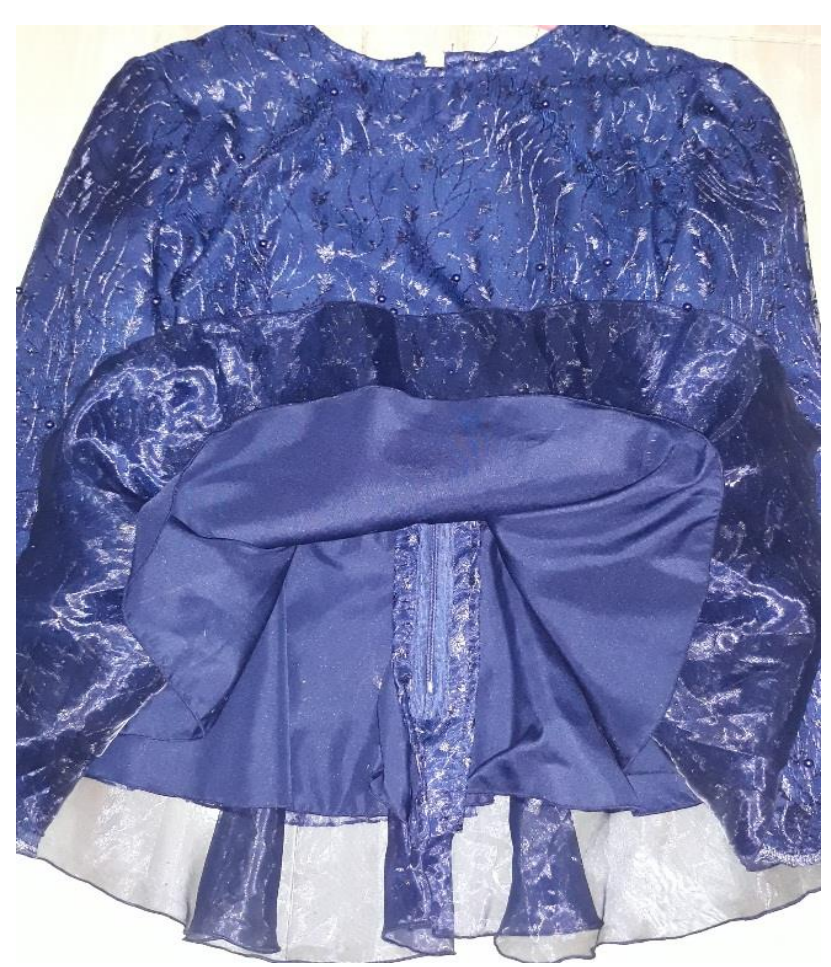

Gambar 8. Furing Pada Gaun

\section{SIMPULAN}

Berdasarkan hasil penelitian ini dapat disimpulkan bahwa masyarakat kampung malaus yang telah mengikuti pelatihan menjahit dapat berwirausaha secara mandiri. Pelatihan menjahit berpengaruh terhadap meningkatnya keterampilan dan kemampuan peserta.

\section{DAFTAR PUSTAKA}

Citra Kunia putri dan trisna insan Noor, 2011. (2013). 済無No Title No Title. Analisis Pendapatan Dan Tingkat Kesejahteraan Rumah Tangga Petani, 53(9), 1689-1699.

MK Bajuri. (2015). No Title p. Phys. Rev. E, 1993, 24. http://ridum.umanizales.edu.co:8080/jspui/bitstream/6789/377/4/Muñoz_Zapata_Adriana_Patricia_ Artículo_2011.pdf

Nurpitriani, A. (2017). Pelaksanaan Pelatihan Menjahit Pakaian Dasar Berbasis Kompetensi di Balai Besar Pengembangan Latihan Kerja Semarang.

Pelatihan, L., \& Aisyah, K. (2020). Volume 1, Nomor 1 Maret 2020 Fakultas keguruan dan Ilmu Pendidikan, Universitas Singaperbangsa Karawang 1. 20, 28-32.

Pitaloka, E. (2007). Pembuatan Busana Pengantin Putri Adat Minangkabau. https://scholar.google.com/scholar?hl=en\&q=kurung+songket+\&btnG=\&as_sdt=1\%2C5\&as_sdtp= \#0

Septyana, H. (2013). Manajemen Pembelajaran Berbasis Kompetensi Pelatihan Menjahit Di Lembaga Pelatihan Kerja Swasta (Lpks) Fortuna Dukuh Siberuk Desa Siberuk Kabupaten Batang. Journal of Non Formal Education and Community Empowerment, 2(2), 46-50.

YENIS FIRISKA, A. (2017). Pelatihan Menjahit Dasar Untuk Membentuk Sikap Wirausaha Peserta Didik Kejar Paket B Di Upt Skb Cerme Gresik. J+Plus Unesa, 6(2), 101-107. 
Yuse, A. P., Jamaris, J., \& Ismaniar, I. (2018). Penerapan Pembelajaran Orang Dewasa oleh Instruktur Pelatihan Keterampilan Menjahit di SPNF SKB Lima Puluh Kota. Spektrum: Jurnal Pendidikan Luar Sekolah (PLS), 1(1), 16. https://doi.org/10.24036/spektrumpls.v1i1.9199 